\title{
RECENT DEVELOPMENTS \\ IN THE STUDY OF CARBORANES
}

\author{
L. J. TODD \\ Department of Chemistry, Indiana University, Bloomington. \\ Indiana 47401 USA
}

\begin{abstract}
A variety of (ligand)-Metal(CO) ${ }_{5}$ complexes have been prepared using germaphospha- and arsacarboranes as sigma-donor ligands. New types of bonding are observed in these complexes. New types of one-carbon carborane derivatives have been obtained by reduction of 1.12- $\mathrm{B}_{10} \mathrm{H}_{10} \mathrm{CHAs}$ and by reaction of $\mathrm{i}-\mathrm{B}_{18} \mathrm{H}_{22}$ with alkyl isocyanides. The $70.6 \mathrm{MHz}{ }^{11} \mathrm{~B} \mathrm{n}$.m.r. spectra of 1,2- $\mathrm{B}_{9} \mathrm{C}_{2} \mathrm{H}_{12}^{-}$- (1.2- $\left.\mathrm{B}_{9} \mathrm{C}_{2} \mathrm{H}_{11}\right)_{2} \mathrm{Co}^{-}$and 1,7- $\mathrm{B}_{10} \mathrm{H}_{10} \mathrm{C}_{2} \mathrm{H}_{2}$ have been elucidated by labelling studies. Correlations of the ${ }^{11} \mathrm{~B}$ and ${ }^{13} \mathrm{C}$ n.m.r. chemical shift data of certain carboranes have been observed.
\end{abstract}

\section{SIGMA-BONDED METAL COMPLEXES OF GERMA-, PHOSPHA- AND ARSACARBORANES AND THEIR DERIVATIVES}

A few years ago we prepared $1,2-\mathrm{B}_{10} \mathrm{H}_{10} \mathrm{CHP}$ and rearranged it thermally to $1,7-\mathrm{B}_{10} \mathrm{H}_{10} \mathrm{CHP}^{1,2}$. A boron atom can be removed from either the 1,2- or 1,7 -isomer by reaction in refluxing piperidine to give $7,8-$ or $7,9-\mathrm{B}_{9} \mathrm{H}_{10} \mathrm{CHP}^{-}$ respectively ${ }^{1-3}$. Attempted methylation of the icosahedral 1,2- and 1,7$\mathrm{B}_{10} \mathrm{H}_{10} \mathrm{CHP}$ molecules was not successful. However, the open-cage anions reacted readily with methyl iodide to form 1,2- and $1,7-\mathrm{B}_{9} \mathrm{H}_{10} \mathrm{CHPCH}_{3}{ }^{2}$. The entering methyl group was found to be attached to the phosphorus atom by an x-ray structure study of a metal complex of one of the phosphacarboranes ${ }^{4}$. This result suggested that the lone pair of electrons on the phosphorus atom might sigma-bond to transition metals.

Irradiation of a tetrahydrofuran solution of $7,8-\mathrm{B}_{9} \mathrm{H}_{10} \mathrm{CHP}^{-}$and $\mathrm{Mo}(\mathrm{CO})_{6}$ with a high pressure mercury-vapour lamp produced 7,8$\mathrm{B}_{9} \mathrm{H}_{10} \mathrm{CHP} \cdot \mathrm{Mo}(\mathrm{CO})_{5}^{-}$in moderate yield ${ }^{5}$. Ten of the twelve possible derivatives of the type $\mathrm{LM}(\mathrm{CO})_{5}^{-}$(where $\mathrm{M}=\mathrm{Cr}$, Mo or $\mathrm{W}$ and $\mathrm{L}=7,8-$ or $7,9-\mathrm{B}_{9} \mathrm{H}_{10} \mathrm{CHP}^{-}$or $7,8-$ or $7,9-\mathrm{B}_{9} \mathrm{H}_{10} \mathrm{CHAs}^{-}$) have been characterized. Evidence suggesting that the phosphorus atom in the carborane ligand is bonded directly to the Group VI metal atom has been obtained from the ${ }^{13} \mathrm{C}$ n.m.r. spectrum of $\left(\mathrm{CH}_{3}\right)_{4} \mathrm{~N}\left[7,9-\mathrm{B}_{9} \mathrm{H}_{10} \mathrm{CHP} \cdot \mathrm{Mo}(\mathrm{Co})_{5}\right]$. The cis and trans carbonyl resonances show phosphorus-carbon spin-spin coupling and appear as doublets at $-4.78 \mathrm{ppm} \dagger\left(J_{13{ }^{3}-31} \mathbf{p}=8 \mathrm{cps}\right)$ and $-7.43 \mathrm{ppm}$

$\dagger$ The ${ }^{13} \mathrm{C}$ chemical shilts are relative to $\mathrm{CS}_{2}=0 \mathrm{ppm}$. 


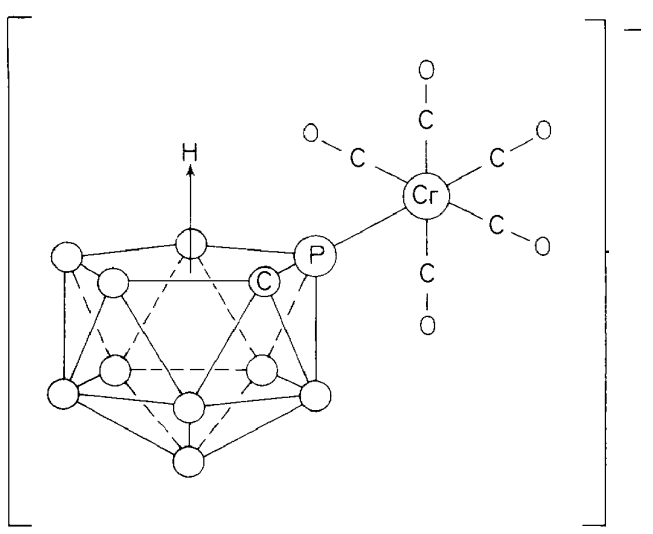

Figure 1. Proposed structure for $\left[7,8-\mathrm{B}_{9} \mathrm{H}_{10} \mathrm{CHP} \cdot \mathrm{Cr}(\mathrm{CO})_{5}\right]^{-}$

$\left(J_{{ }_{13} \mathrm{C}_{-3}{ }^{1} \mathrm{P}}=26 \mathrm{cps}\right) \cdot$ respectively. The proposed structure for $[7,8-$ $\left.\mathrm{B}_{9} \mathrm{H}_{10} \mathrm{CHP} \cdot \mathrm{Cr}(\mathrm{CO})_{5}\right]^{-}$and the other anionic complexes in this series is given in Fiqure 1.

The complex $\left(1,7-\mathrm{B}_{9} \mathrm{H}_{9} \mathrm{CHP}\right)_{2} \mathrm{Fe}^{2-}$ can be methylated on the phosphorus atoms ${ }^{4,6}$. Thus it seemed probable that the eleven-atom phosphacarborane ligand might function simultaneously as a $\pi$-bonded ligand to one metal and a sigma-bonded ligand to a second metal. An attempt to remove a proton from 7,9- $\mathrm{B}_{9} \mathrm{H}_{10} \mathrm{CHP} \cdot \mathrm{Cr}(\mathrm{CO})_{5}^{-}$and $\pi$-bond the dianion with iron(II) chloride was not successful. The photochemical reaction described below, however, gave the desired product.

$$
\begin{aligned}
\left(1,7-\mathrm{B}_{9} \mathrm{H}_{9} \mathrm{CHE}\right)_{2} \mathrm{Fe}^{2-}+\mathrm{M}(\mathrm{CO})_{6} \stackrel{\text { u.v. }}{\rightarrow}\left\{\mathrm{Fe}\left[1,7-\mathrm{B}_{9} \mathrm{H}_{9} \mathrm{CHE} \cdot \mathrm{M}(\mathrm{CO})_{5}\right]_{2}\right\}^{2-} \\
\mathrm{E}=\mathrm{P} ; \mathrm{M}=\mathrm{Cr}, \mathrm{Mo} \text { or } \mathrm{W} \\
\mathrm{E}=\mathrm{As} ; \mathrm{M}=\mathrm{Cr}
\end{aligned}
$$

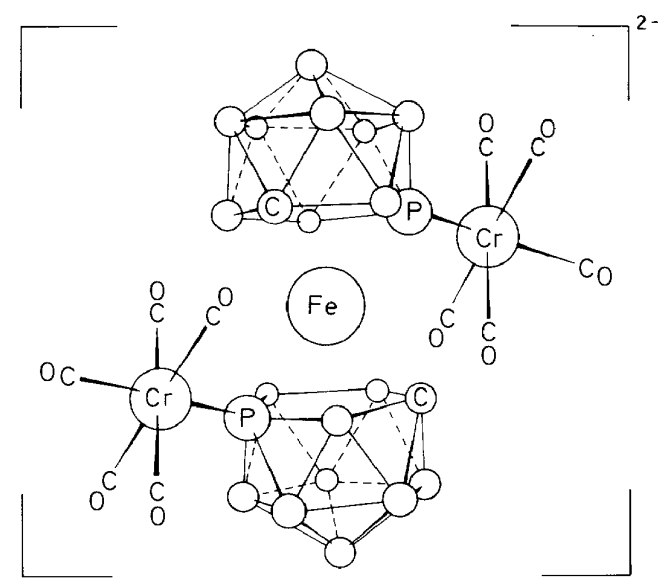

Figure 2. Proposed structure for $\left[1,7-\mathrm{B}_{9} \mathrm{H}_{9} \mathrm{CHP} \cdot \mathrm{Cr}(\mathrm{CO})_{5}\right]_{2} \mathrm{Fe}^{2-}$ 


\section{RECENT DEVELOPMENTS IN THE STUDY OF CARBORANES}

To date these three-metal complexes have been characterized by elemental analyses. osmometer molecular weight, infrared and ${ }^{13} \mathrm{C}$ n.m.r. Again apparent phosphorus-carbon spin coupling was observed with the cis carbonyl carbon resonance in the ${ }^{13} \mathrm{C}$ n.m.r. spectrum of one of these complexes. The proposed structure for the three-metal complexes is presented in Figure 2.

A neutral phosphacarborane ligand can be obtained by an 'oxidative-substitution' process on $7,9-\mathrm{B}_{9} \mathrm{H}_{10} \mathrm{CHP}^{-}$as illustrated in the following reaction.

$\left.7.9-\mathrm{B}_{9} \mathrm{H}_{10} \mathrm{CHP}^{-}+\mathrm{N} \bigcirc\right\rangle^{\mathrm{Br}}+\mathrm{FeCl}_{3} \rightarrow 7,9-\mathrm{B}_{9} \mathrm{H}_{9}(\mathrm{~N} \bigcirc\rangle^{\mathrm{Br}} \mathrm{CHP}+\mathrm{FeCl}_{2}+\mathrm{HCl}$

This substitution reaction was first reported by Hawthorne and co-workers employing the 1,2- $\mathrm{B}_{9} \mathrm{H}_{10} \mathrm{C}_{2} \mathrm{H}_{2}^{-}$ion? ${ }^{7}$. With ultraviolet irradiation the neutral phosphine ligand reacts readily with chromium hexacarbonyl.

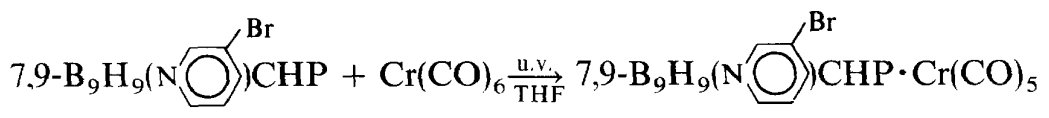

This neutral complex is much simpler to purify and characterize than the previously described anionic complexes and may be preferred in the synthesis of other types of phosphine-metal complexes.

Graham has defined $\sigma$ and $\pi$ parameters of a ligand in a (ligand) $\mathrm{M}(\mathrm{CO})_{5}$ complex in terms of the effect of the ligand on the $\mathrm{CO}$ force constants ${ }^{8}$.

Table 1. Graham $\sigma$ and $\pi$ parameters for some $\mathrm{LM}(\mathrm{CO})_{5}$ complexes $^{\dagger}$

\begin{tabular}{|c|c|c|c|}
\hline L & M & $\begin{array}{c}\sigma \\
\operatorname{mdyn} / A\end{array}$ & $\begin{array}{c}\pi \\
\operatorname{mdyn} / \mathrm{A}\end{array}$ \\
\hline $\begin{array}{l}\mathrm{P}\left(\mathrm{C}_{6} \mathrm{H}_{5}\right)_{3}{ }^{9} \\
7,8-\mathrm{B}_{0} \mathrm{H}_{10} \mathrm{CHP}^{-}\end{array}$ & $\begin{array}{l}\mathrm{Cr} \\
\mathrm{Cr}\end{array}$ & $\begin{array}{l}-0.27 \\
+0.15\end{array}$ & $\begin{array}{l}+0.35 \\
-0.04\end{array}$ \\
\hline $7.8-\mathrm{B}_{9} \mathrm{H}_{9}\left(\mathrm{~N}^{\prime} \bigcirc\right)_{{ }_{\mathrm{CHP}}}$ & $\mathrm{Cr}$ & +0.18 & -0.07 \\
\hline $\begin{array}{l}7.9-\mathrm{B}_{9} \mathrm{H}_{10} \mathrm{CHP}^{-} \\
{\left[\mathrm{Fe}\left(1,7-\mathrm{B}_{9} \mathrm{H}_{9} \mathrm{CHP}\right)_{2}\right]^{2-}} \\
\mathrm{PF}_{3}{ }^{8} \\
\mathrm{P}\left(\mathrm{OC}_{6} \mathrm{H}_{5}\right)_{3}{ }^{8} \\
\mathrm{P}\left(\mathrm{C}_{6} \mathrm{H}_{5}\right)_{3}{ }^{8} \\
7.9-\mathrm{B}_{9} \mathrm{H}_{10} \mathrm{CHP}^{-} \\
{\left[\mathrm{Fe}\left(1,7-\mathrm{B}_{9} \mathrm{H}_{9} \mathrm{CHP}\right)_{2}\right]^{2-}}\end{array}$ & $\begin{array}{l}\mathrm{Cr} \\
\mathrm{Cr} \\
\mathrm{Mo} \\
\mathrm{Mo} \\
\mathrm{Mo} \\
\mathrm{Mo} \\
\mathrm{Mo}\end{array}$ & $\begin{array}{l}+0.21 \\
+0.26 \\
-0.09 \\
-0.13 \\
-0.15 \\
+0.35 \\
+0.45\end{array}$ & $\begin{array}{l}-0.12 \\
-0.26 \\
+0.79 \\
+0.48 \\
+0.27 \\
-0.21 \\
-0.39\end{array}$ \\
\hline
\end{tabular}

+ The relerence compound is (Cyclohexylamine)-Metal $(\mathrm{CO})_{5}: \sigma=0 . \pi=0$.

In Table 1 the $\sigma$ and $\pi$ parameters of some phosphine-metal pentacarbonyl derivatives are presented. According to Graham's method the phosphacarborane ligands are poorer sigma-donors than all other phosphines and all have an 'apparent $\pi$-donor character.' 


\section{J. TODD}

Icosahedral germacarboranes can be prepared by the following reaction ${ }^{10}$.

$$
\mathrm{CH}_{3} \mathrm{GeCl}_{3}+\mathrm{Na}_{3} \mathrm{~B}_{10} \mathrm{H}_{10} \mathrm{CH} \rightarrow 1,2-\mathrm{B}_{10} \mathrm{H}_{10} \mathrm{CHGeCH}_{3}
$$

An attempt to remove a boron atom from the cage with piperidine resulted in removal of the alkyl group on the germanium atom to yield the icosahedral anion ${ }^{10}, 1,2-\mathrm{B}_{10} \mathrm{H}_{10} \mathrm{CHGe}^{-}$. This anion can be realkylated to generate the neutral carborane. Several examples of sigma-bonded transition metal complexes involving carborane-carbon to metal single bonds have been reported recently ${ }^{11}$. This information led us to investigate the reaction indicated below.

$$
\begin{gathered}
1,2-\mathrm{B}_{10} \mathrm{H}_{10} \mathrm{CHGe}^{-}+\mathrm{M}\left(\mathrm{CO}_{6} \frac{\mathrm{u} \cdot \mathrm{v}_{\mathrm{.}}}{\mathrm{THF}}\left[1,2-\mathrm{B}_{10} \mathrm{H}_{10} \mathrm{CHGe} \cdot \mathrm{M}(\mathrm{CO})_{5}\right]^{-}\right. \\
\mathrm{M}=\mathrm{Cr}, \mathrm{Mo} \text { or W }
\end{gathered}
$$

Sigma-bonded complexes of the germacarborane with Group VI metal carbonyls have been characterized. We propose the structure presented in Figure 3 for this type of complex.
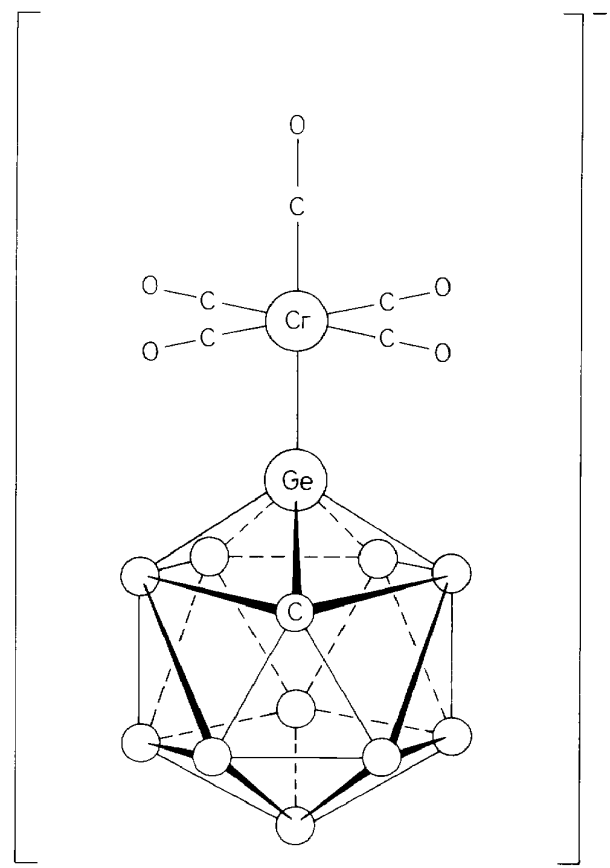

Figure 3. Proposed structure for $\left[1,2-\mathrm{B}_{10} \mathrm{H}_{10} \mathrm{CHGe} \cdot \mathrm{Cr}(\mathrm{CO})_{5}\right]^{-}$

\section{CARBORANE AND METAL DERIVATIVES OF $\mathrm{B}_{18} \mathrm{H}_{22}$}

The two isomers of $\mathrm{B}_{18} \mathrm{H}_{22}$ can be conveniently made in laboratory quantities by oxidative coupling of $\mathrm{B}_{10} \mathrm{H}_{10}^{2-}$ with ferric chloride to form $\mathrm{B}_{20} \mathrm{H}_{18}^{2-}$ and subsequent controlled acid hydrolysis to $\mathrm{B}_{18} \mathrm{H}_{22}{ }^{12}$. The structures of the two isomers have been determined by $\mathrm{x}$-ray studies ${ }^{13,14}$. 


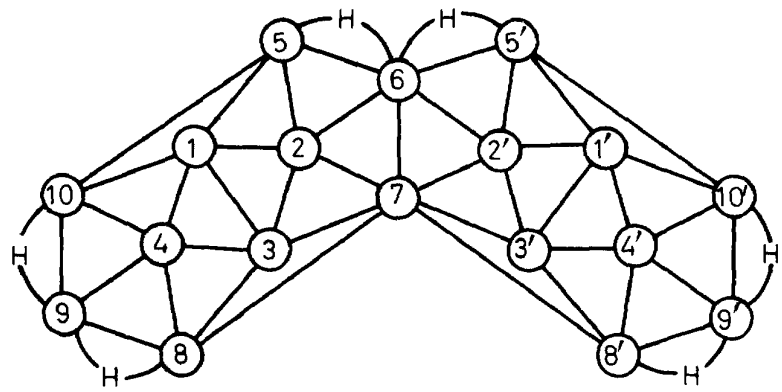

Figure 4. The structure and numbering system of iso- $\mathrm{B}_{18} \mathrm{H}_{22}$

The $\mathrm{B}_{18} \mathrm{H}_{22}$ isomers are formally related to $\mathrm{B}_{10} \mathrm{H}_{14}$ and can be viewed as two decaborane molecules which are joined together and share in common atoms $\mathrm{B}(6)$ and $\mathrm{B}(7)$ in the decaborane numbering system (see Figure 4). Owing to the structural similarity to decaborane, we have investigated some atom insertion reactions with the $\mathrm{B}_{18} \mathrm{H}_{22}$ isomers which were successful with $\mathrm{B}_{10} \mathrm{H}_{14}$.

Deprotonation of $n-\mathrm{B}_{18} \mathrm{H}_{22}$ with sodium hydride to $\mathrm{n}-\mathrm{B}_{18} \mathrm{H}_{20}^{2-}$ and reaction of the dianion with $\mathrm{Co}_{2}(\mathrm{CO})_{8}$ produced the red complex. $\left[(\mathrm{CO})_{3} \mathrm{Co}\left(\mathrm{n}-\mathrm{B}_{18} \mathrm{H}_{20}\right)\right]^{-}$. This metal insertion reaction has been applicable to several other transition metals ${ }^{15}$ and some examples are presented in Table 2. A series of transition metal complexes such as $\left[(\mathrm{CO})_{3} \mathrm{Co}\left(\mathrm{B}_{10} \mathrm{H}_{12}\right)\right]^{-}$

Table 2. Types of $\mathrm{B}_{18} \mathrm{H}_{20}^{2-}$ transition metal complexes

\begin{tabular}{ll}
\hline \multicolumn{1}{c}{ Starting material } & \multicolumn{1}{c}{ Product } \\
\hline $\mathrm{Co}_{2}(\mathrm{CO})_{8}$ & $\left(\mathrm{n}-\mathrm{B}_{18} \mathrm{H}_{20}\right) \mathrm{Co}(\mathrm{CO})_{3}^{-}$ \\
$\left(\mathrm{PPh}_{3}\right)_{2} \mathrm{Rh}(\mathrm{CO}) \mathrm{Cl}$ & $\left(\mathrm{n}-\mathrm{B}_{18} \mathrm{H}_{20}\right) \mathrm{Rh}(\mathrm{CO}) \mathrm{PPh}_{3}^{-}$ \\
$\left(\mathrm{PPh}_{3}\right)_{2} \mathrm{NiCl}_{2}$ & $\left(\mathrm{n}-\mathrm{B}_{18} \mathrm{H}_{20}\right) \mathrm{Ni}(\mathrm{PPh})_{2}$ \\
$(\mathrm{Diphos}) \mathrm{NiCl}_{2}$ & $\left(\mathrm{n}-\mathrm{B}_{18} \mathrm{H}_{20}\right) \mathrm{Ni}(\mathrm{Diphos})$ \\
$(\mathrm{Diphos}) \mathrm{MCl}_{2}$ & $\left(\mathrm{i}-\mathrm{B}_{18} \mathrm{H}_{20}\right) \mathrm{M}(\mathrm{Diphos})_{\mathrm{M}}$ \\
$\mathrm{M}=\mathrm{Ni}, \mathrm{Pd}$ or Pt & Diphos $=\mathrm{Ph}_{2} \mathrm{PCH}_{2} \mathrm{CH}_{2} \mathrm{PPh}_{2}$ \\
\hline
\end{tabular}

have been prepared and characterized ${ }^{16}$. Barring rearrangement, we suggest that the metal-borane bonding in the complexes of $\mathrm{B}_{18} \mathrm{H}_{20}^{2-}$ and $\mathrm{B}_{10} \mathrm{H}_{12}^{2-}$ are similar. The proposed structure is given in Figure 5.

Decaborane-14 reacts with one equivalent of alkyl isocyanide to produce a one-carbon carborane of the general formula $\mathrm{B}_{10} \mathrm{H}_{12} \mathrm{CNH}_{2} \mathrm{R}^{17}$. The second boron hydride which has been found to undergo this reaction is $\mathrm{i}-\mathrm{B}_{18} \mathrm{H}_{22}$.

$$
\mathrm{i}-\mathrm{B}_{18} \mathrm{H}_{22}+\mathrm{C}_{6} \mathrm{H}_{11} \mathrm{~N} \equiv \mathrm{C} \rightarrow \mathrm{B}_{18} \mathrm{H}_{28} \mathrm{CNH}_{2} \mathrm{C}_{6} \mathrm{H}_{11}
$$

The $\mathrm{NH}_{2}$ function is observed in the infrared spectrum and in the proton n.m.r. spectrum. The proposed structure for this new one-carbon carborane is presented in Figure 6. Transition metals can be inserted into the carborane derivative by the following process. The metal atom may have

$\mathrm{B}_{18} \mathrm{H}_{20} \mathrm{CNH}_{2} \mathrm{C}_{6} \mathrm{H}_{11}+2 \mathrm{NaH}+($ Diphos $) \mathrm{NiCl}_{2} \rightarrow$

$\left(\mathrm{B}_{18} \mathrm{H}_{18} \mathrm{CNH}_{2} \mathrm{C}_{6} \mathrm{H}_{11}\right) \mathrm{Ni}$ (Diphos) 


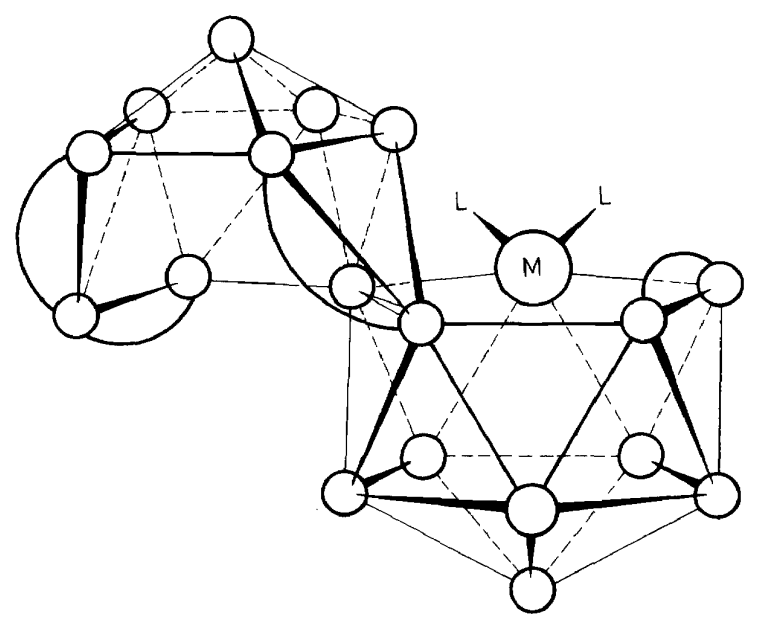

Figure 5. Proposed structure of $\left(\mathrm{n}-\mathrm{B}_{18} \mathrm{H}_{20}\right)$ Metal(ligand $)_{2}$ complexes

inserted into the other open face of the $\mathrm{B}_{18}$ structure and therefore would not be bonded to the carbon-containing open face at all. Structural models suggest that this is the least congested alternative. Further study is needed to clarify this point.

\section{ACID DEGRADATION OF ELECTRON-RICH CARBORANES}

The icosahedral carboranes can be reduced with sodium metal in liquid ammonia to a dianion ${ }^{18,19}$.

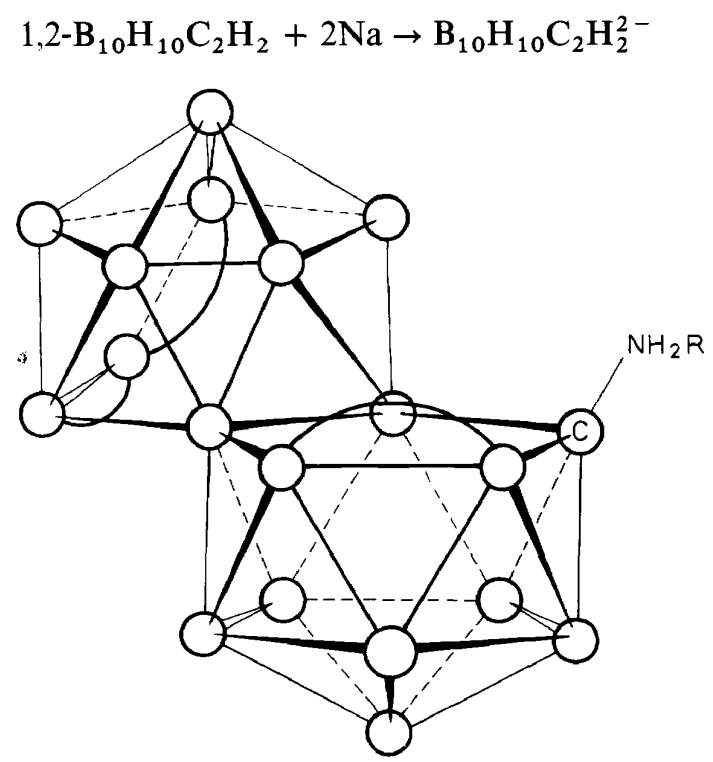

Figure 6. Proposed structure of $\mathrm{B}_{18} \mathrm{H}_{20} \mathrm{CNH}_{2} \mathrm{R}$ 


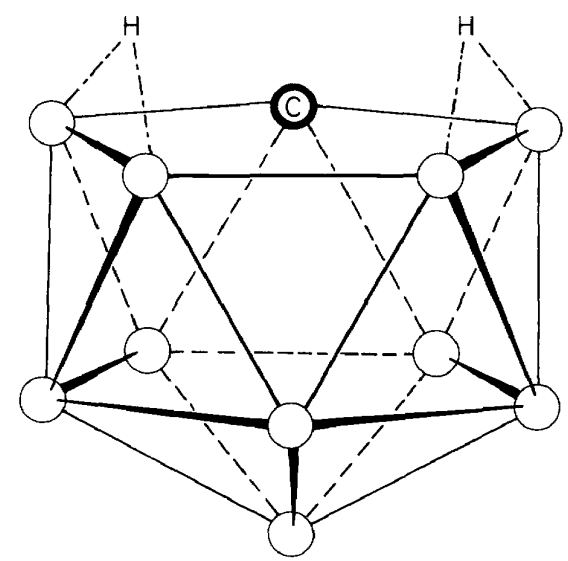

Figure 7. Proposed structure of $\mathrm{B}_{10} \mathrm{H}_{12} \mathrm{CH}^{-}$

Hawthorne has recently demonstrated that the dianion is an open-cage species by converting it to the transition metal complex, $\left(\mathrm{B}_{10} \mathrm{H}_{10} \mathrm{C}_{2} \mathrm{H}_{2}\right) \mathrm{Co}\left(\mathrm{C}_{5} \mathrm{H}_{5}\right)^{20}$. We have looked at the reduction of phospha- and arsacarboranes with sodium metal. Oxidation of the products regenerates neutral phospha- and arsacarboranes. The phosphacarborane 1,12- and 1,7-isomers give the same type of rearrangements in the reduction-oxidation procedure as do the corresponding isomers of $\mathrm{B}_{10} \mathrm{H}_{10} \mathrm{C}_{2} \mathrm{H}_{2}$. If $1,2-\mathrm{B}_{10} \mathrm{H}_{10} \mathrm{CHE}^{2-}(\mathrm{E}=\mathrm{P}$ or $\mathrm{As})$ is treated with aqueous acid, the Group $\mathrm{V}$ atom is removed from the cage and $\mathrm{B}_{10} \mathrm{H}_{12} \mathrm{CH}^{-}$is obtained as a major product. In this case the carbon atom is in the open face as indicated in Figure 7. Acid hydrolysis of 1,12$\mathrm{B}_{10} \mathrm{H}_{10} \mathrm{CHE}^{2-}\left(\mathrm{E}=\mathrm{P}\right.$ or As) also produces $\mathrm{B}_{10} \mathrm{H}_{12} \mathrm{CH}^{-}$. However, under controlled conditions, acid hydrolysis of $1,12-\mathrm{B}_{10} \mathrm{H}_{10} \mathrm{CHAs}^{2-}$ has given a new isomer, iso- $\mathrm{B}_{10} \mathrm{H}_{12} \mathrm{CH}^{-}$. This new carborane anion has a simple ${ }^{11} \mathrm{~B}$ n.m.r. spectrum consisting of two doublets of equal intensity. A phosphorus atom has been inserted into iso- $\mathrm{B}_{10} \mathrm{H}_{12} \mathrm{CH}^{-}$by the following method.

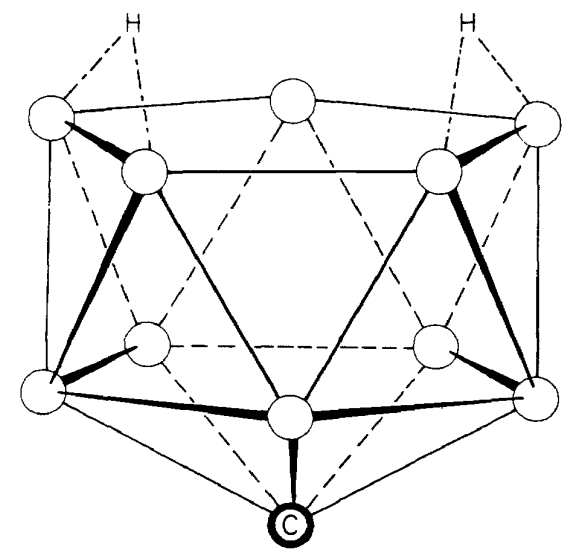

Figure 8. Proposed structure of iso- $\mathrm{B}_{10} \mathrm{H}_{12} \mathrm{CH}^{-}$ 


\section{J. TODD}

$$
\mathrm{i}-\mathrm{B}_{10} \mathrm{H}_{12} \mathrm{CH}^{-} \underset{\mathrm{NaH}}{\stackrel{\mathrm{THF}}{\mathrm{f}}} \frac{\text { (1) remove solvent }}{(2) \mathrm{PCl}_{3} \text {. toluen }} 1,12-\mathrm{B}_{10} \mathrm{H}_{10} \mathrm{CHP}
$$

The removal of an arsenic atom from 1,12- $\mathrm{B}_{10} \mathrm{H}_{10} \mathrm{CHAs}$ and the reinsertion of a phosphorus atom to generate $1,12-\mathrm{B}_{10} \mathrm{H}_{10} \mathrm{CHP}$ suggests that iso$\mathrm{B}_{10} \mathrm{H}_{12} \mathrm{CH}^{-}$is the tridecahydro-1-carba-nido-undecaborate $(1-)$ ion. The proposed structure of this ion is given in Figure 8.

\section{BORON-11 AND CARBON-13 N.M.R. STUDIES OF SOME CARBORANE DERIVATIVES}

Unlike proton n.m.r., there is still a lack of understanding of the factors important in explaining ${ }^{11} \mathbf{B}$ n.m.r. chemical shifts. We have undertaken a systematic study of the boron n.m.r. spectra of various classes of boron hydrides $^{21,22}$ and carboranes. We hope these studies will give further insight into the boron chemical shift problems as well as to provide new information about the structure and bonding in these molecules.

The $70.6 \mathrm{MHz}{ }^{11} \mathrm{~B}$ n.m.r. spectrum of $1,2-\mathrm{B}_{9} \mathrm{C}_{2} \mathrm{H}_{12}^{-}$is presented in Figure 9. The doublet of unit area at $+33.1 \mathrm{ppm} \dagger$ exhibits secondary coupling to the unique proton which is apparently bridge bonded to the open face of the anion. The fine structure can be removed by proton decoupling the bridge proton region as well as by deuterium exchange of the bridge proton. This information suggests that the $+33.1 \mathrm{ppm}$ doublet is associated with $\mathrm{B}(8)$, the unique boron in the open face. The remainder of the spectrum was assigned by examining a series of specifically labelled derivatives. The ${ }^{11} \mathrm{~B}$ n.m.r.

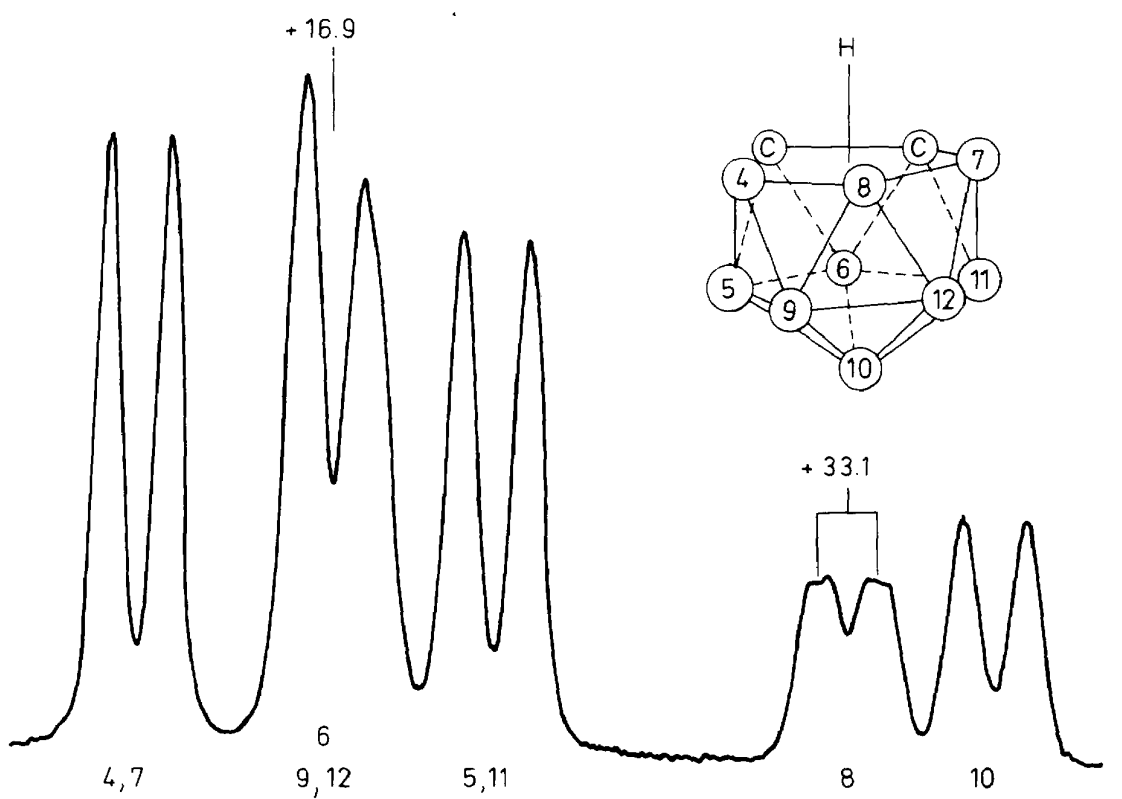

Figure 9. The $70.6 \mathrm{MHz}{ }^{11}$ B n.m.r. spectrum of $\left(\mathrm{CH}_{3}\right)_{3} \mathrm{NH}\left[1,2-\mathrm{B}_{9} \mathrm{C}_{2} \mathrm{H}_{12}\right]$ in acetonitrile solution

$\left\lceil{ }^{11} \mathrm{~B}\right.$ chemical shifts are relative to $\mathrm{BF}_{3} \cdot \mathrm{O}\left(\mathrm{C}_{2} \mathrm{H}_{5}\right)_{2}=0 \mathrm{ppm}$. 


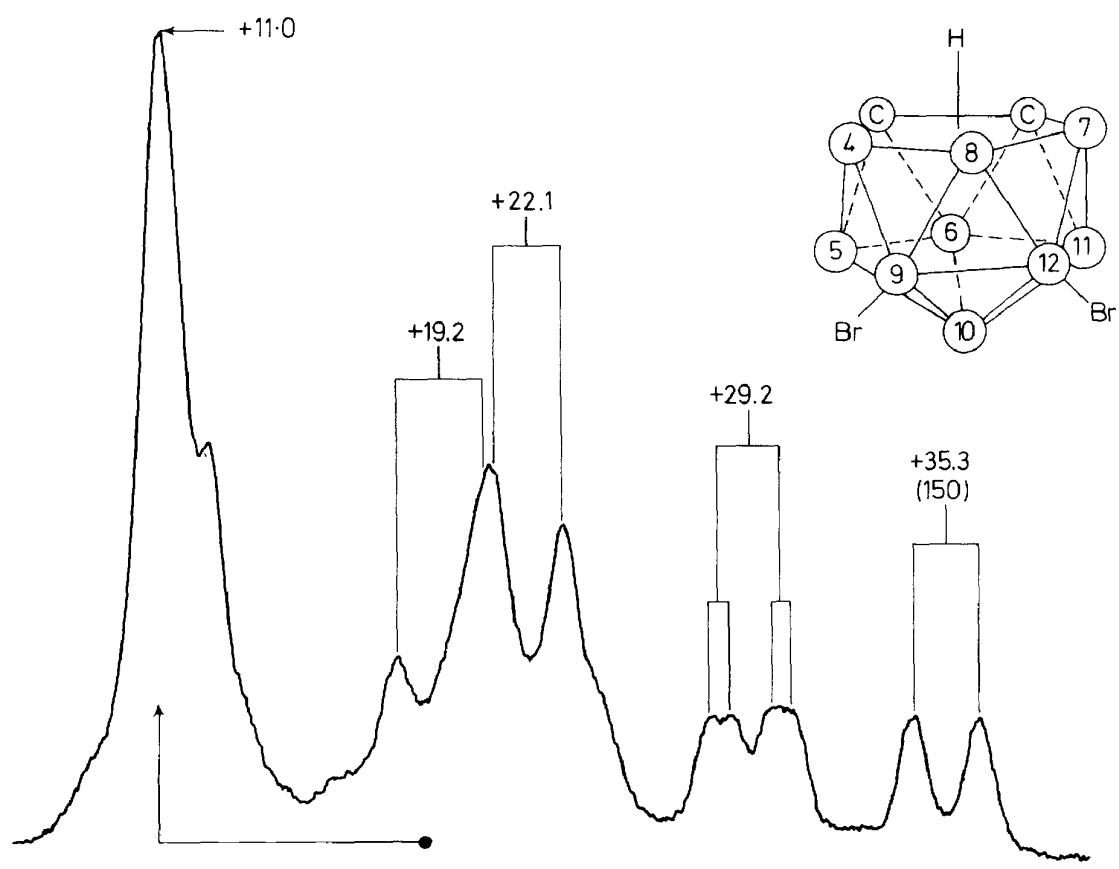

Figure 10. The $70.6 \mathrm{MHz}{ }^{11} \mathrm{~B}$ n.m.r. spectrum of $\left(\mathrm{CH}_{3}\right)_{4} \mathrm{~N}\left[9,12-\mathrm{Br}_{2}-1.2-\mathrm{B}_{9} \mathrm{C}_{2} \mathrm{H}_{10}\right]$ in acetonitrile

spectrum of $9,12-\mathrm{Br}_{2}-1,2-\mathrm{B}_{9} \mathrm{C}_{2} \mathrm{H}_{10}^{-}$is given in Figure 10. Upon bromine substitution a boron resonance generally is found at lower field than its position in the unsubstituted derivative. A doublet of area two at $+16.9 \mathrm{ppm}$ in the spectrum of the parent compound is missing in Figure 10 and a large singlet has appeared at $+11 \mathrm{ppm}$. This suggests that the doublet at $+16.9 \mathrm{ppm}$ in Figure 9 is associated with $B(9,12)$. Using the same type of strategy with other substituted derivatives, the assignments given at the bottom of Figure 9 were determined ${ }^{24}$.

The 1,2- $\mathrm{B}_{9} \mathrm{C}_{2} \mathrm{H}_{12}^{-}$ion or the labelled derivatives described in the previous section can be deprotonated with bases and reacted with cobalt(II) chloride to insert the cobalt atom into the open face of the carborane cage to form $\left(1,2-\mathrm{B}_{9} \mathrm{C}_{2} \mathrm{H}_{11}\right)_{2} \mathrm{Co}^{-}$or labelled derivatives. The $70.6 \mathrm{MHz}{ }^{11} \mathrm{~B}$ n.m.r. spectrum of $\left(1,2-\mathrm{B}_{9} \mathrm{C}_{2} \mathrm{H}_{11}\right)_{2} \mathrm{Co}^{-}$is given in Figure 11. The spectrum contains five doublets of relative intensities $1: 1: 4: 2: 1$, reading upfield. The proposed assignment of these doublets is $\mathrm{B}(8) ; \mathrm{B}(10) ; \mathrm{B}(9,12)$ and $\mathrm{B}(4,7)$ for the doublet of area four; $\mathrm{B}(5,11)$ and $\mathrm{B}(6)$ respectively. Comparison of the spectra of the $1,2-\mathrm{B}_{9} \mathrm{C}_{2} \mathrm{H}_{12}^{-}$ion and its cobalt(III) complex indicates an extensive reordering of the relative positions of the boron-11 resonances. Possibly a better correlation of boron resonance positions will be between related icosahedral species, e.g. $\left(1,2-\mathrm{B}_{9} \mathrm{C}_{2} \mathrm{H}_{11}\right)_{2} \mathrm{Co}^{-}$and 3-Ph-1,2- $\mathrm{B}_{10} \mathrm{H}_{9} \mathrm{C}_{2} \mathrm{H}_{2}$.

The $70.6 \mathrm{MHz}$ spectrum of $1,7-\mathrm{B}_{10} \mathrm{H}_{10} \mathrm{C}_{2} \mathrm{H}_{2}$ is given in Figure 12 and contains four doublets of relative intensities $2: 2: 4: 2$. reading upfield. Using labelled derivatives the proposed assignment of these doublets is $\mathrm{B}(5,12) ; \mathrm{B}(9,10) ; \mathrm{B}(4,6,8,11)$ and $\mathrm{B}(2,3)$ respectively ${ }^{23}$. It has been suggested 
L. J. TODD
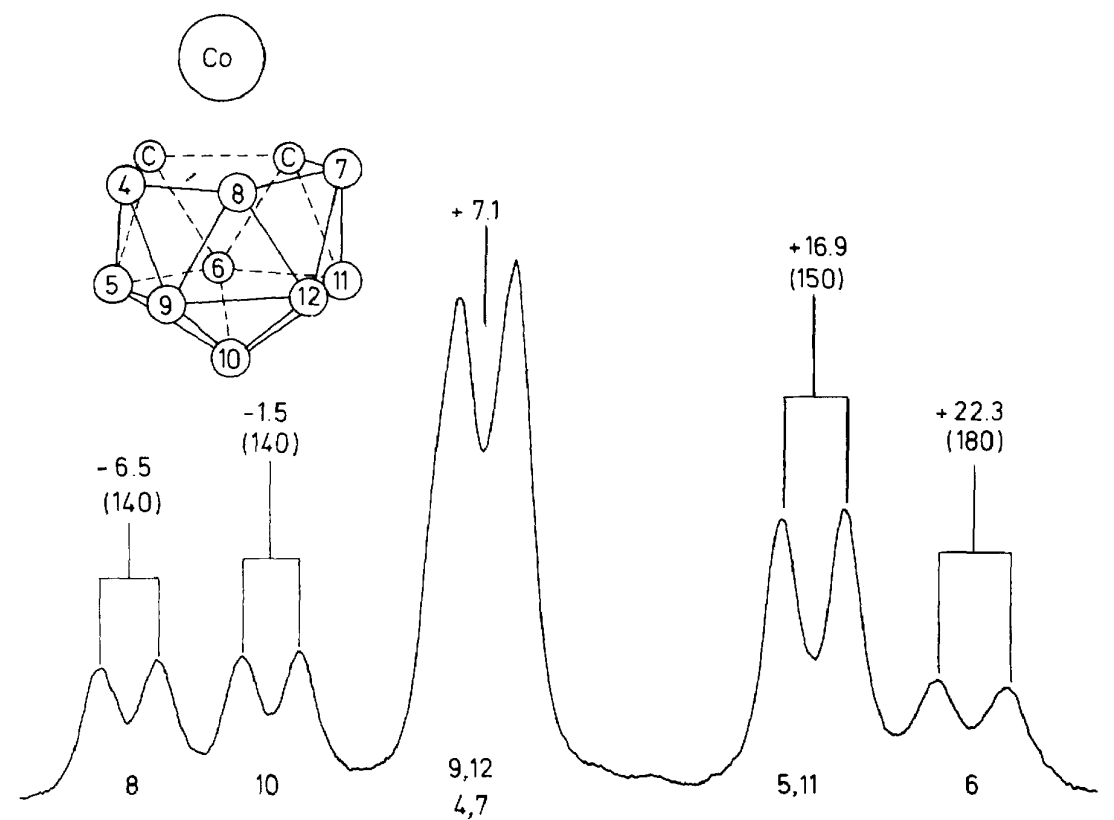

Figure 11. The $70.6 \mathrm{MHz}{ }^{11} \mathrm{~B}$ n.m.r. spectrum of $\left(\mathrm{CH}_{3}\right)_{4} \mathrm{~N}\left[1,2-\mathrm{B}_{9} \mathrm{C}_{2} \mathrm{H}_{11}\right]_{2} \mathrm{Co}$ in acetone solution

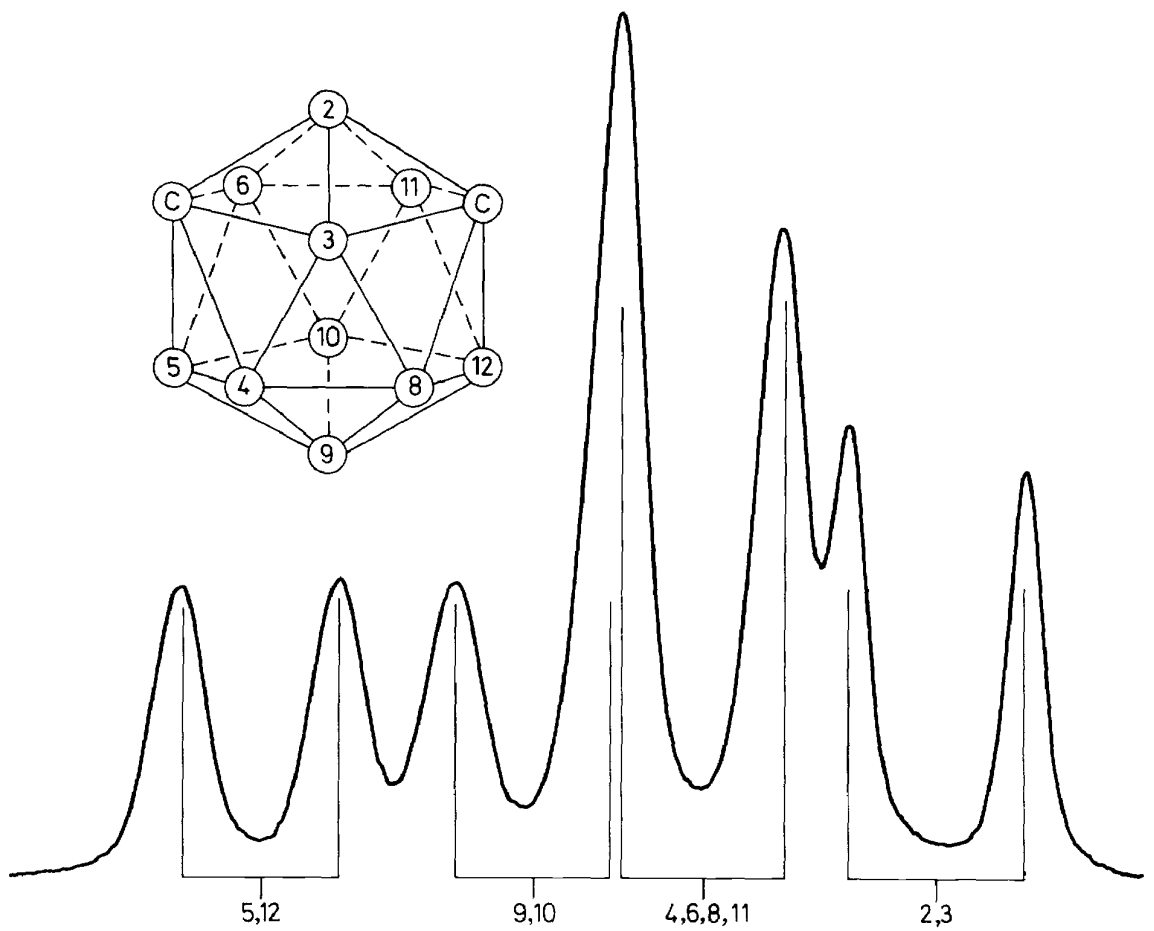

Figure 12. The $70.6 \mathrm{MHz}{ }^{11} \mathrm{~B}$ n.m.r. spectrum of $1,7-\mathrm{B}_{10} \mathrm{H}_{10} \mathrm{C}_{2} \mathrm{H}_{2}$ in acetone solution 


\section{RECENT DEVELOPMENTS IN THE STUDY OF CARBORANES}

that boron chemical shifts can be explained on the basis of a difference primarily in the paramagnetic shielding of boron atoms in different chemical environments. Our results with $\mathrm{m}-\mathrm{B}_{10} \mathrm{H}_{10} \mathrm{C}_{2} \mathrm{H}_{2}$ unfortunately produce more scatter in the least squares correlation given in this reference ${ }^{25}$.

${ }^{11} \mathrm{~B}$ and ${ }^{13} \mathrm{C}$ n.m.r. chemical shift data for some substituted $\mathrm{m}-\mathrm{B}_{10} \mathrm{H}_{10} \mathrm{C}_{2} \mathrm{H}_{2}$ derivatives is given in Table 3.

Table 3. Boron-11 and Carbon-13 chemical shift data for some $1.7-\mathrm{B}_{10} \mathrm{H}_{10} \mathrm{C}_{2} \mathrm{H}_{2}$ derivatives

\begin{tabular}{|c|c|c|c|c|c|}
\hline \multirow{2}{*}{ Compound } & \multicolumn{4}{|c|}{${ }^{11} \mathrm{~B}$ n.m.r. chemical shifts $\dagger$} & \multirow{2}{*}{$\begin{array}{c}{ }^{13} \mathrm{C} \text { shift } \\
1,7\end{array}$} \\
\hline & 5,12 & 9,10 & $4,6,8,11$ & 2.3 & \\
\hline \multicolumn{6}{|l|}{$\mathrm{HCB}_{10} \mathrm{H}_{8} \mathrm{Br}_{2} \mathrm{CH}$} \\
\hline (9.10-dibromo isomer) & 6.0 & 7.0 & 12.4 & 21.0 & 139.7 \\
\hline $\mathrm{HCB}_{10} \mathrm{H}_{10} \mathrm{CH}$ & 6.5 & 10.4 & 12.8 & 16.3 & 137.4 \\
\hline$\left(\mathrm{CH}_{3}\right)_{3} \mathrm{SiCB}_{10} \mathrm{H}_{10} \mathrm{CSi}\left(\mathrm{CH}_{3}\right)_{3}$ & 2.4 & 7.1 & 9.1 & 13.3 & 125.4 \\
\hline $\mathrm{CH}_{3} \mathrm{SCB}_{10} \mathrm{H}_{10} \mathrm{CSCH}_{3}$ & 5.8 & 9.7 & 9.7 & 11.6 & 120.1 \\
\hline
\end{tabular}

+ in ppm relative to $\mathrm{BF}_{3} \cdot \mathrm{O}\left(\mathrm{C}_{2} \mathrm{H}_{5}\right)_{2}$.

$\ddagger$ in ppm relative to $\mathrm{CS}_{2}$

Boron-11 and Carbon-13 chemical shifts would be expected to be influenced by the same factors in closely related chemical environments. Positions $\mathrm{C}(1)$ and $\mathrm{C}(7)$ are adjacent to both $\mathrm{B}(2)$ and $\mathrm{B}(3)$ in the icosahedral surface. It is observed that these positions experience chemical shift changes in the same direction upon substitution. There is much less regular correlation observed between other (boron-carbon) sets of chemical shifts.

A relationship between the ${ }^{11} \mathrm{~B}$ n.m.r. chemical shift and the boron atom coordination number has been observed for carboranes and other polyhedral borane derivatives ${ }^{26}$. That is, within a given carborane molecule, boron atoms of lowest coordination number have the lowest field chemical shift in the ${ }^{11} \mathrm{~B}$ n.m.r. spectrum. A correlation between the ${ }^{13} \mathrm{C}$ and ${ }^{11} \mathrm{~B}$ chemical shifts of alkanes and analogous boron-nitrogen compounds (coordination number $=4$ ) has been observed ${ }^{27}$. We have completed a c.m.r. study which suggests that there is a relationship between the c.m.r. chemical shift and the carbon atom coordination number (C.N. $=4,5$ or 6$)$ in a series of polyhedral carboranes of the general type $\mathrm{B}_{n} \mathrm{C}_{2} \mathrm{H}_{n+2}(\mathrm{n}=3$ to 10). 1,6-Dicarba-closodecaborane(10) has $\mathrm{C}(1)$ in a five-coordinate position and $\mathrm{C}(6)$ in a sixcoordinate position. As indicated in Table 4, there is a $24 \mathrm{ppm}$ difference in

Table 4. Carbon-13 n.m.r. chemical shift data for some polyhedral carboranes

\begin{tabular}{lccl}
\hline Compound & $\begin{array}{c}\text { Coordination } \\
\text { number of carbon }\end{array}$ & $\delta_{\mathrm{C}^{\dagger}}$ & \multicolumn{1}{c}{ Solvent } \\
\hline $1.2-\mathrm{B}_{10} \mathrm{C}_{2} \mathrm{H}_{12}$ & 6 & 137.3 & acetone \\
$1.7-\mathrm{B}_{10} \mathrm{C}_{2} \mathrm{H}_{12}$ & 6 & 137.4 & acetone \\
$1,12-\mathrm{B}_{10} \mathrm{C}_{2} \mathrm{H}_{12}$ & 6 & 129.3 & acetone \\
$1,6-\mathrm{B}_{8} \mathrm{C}_{2} \mathrm{H}_{10}$ & $6(5)$ & $159.4(135.7)$ & acetone \\
$4,5-\mathrm{B}_{7} \mathrm{C}_{2} \mathrm{H}_{9}$ & 5 & 122.5 & acetone \\
$1,6-\mathrm{B}_{4} \mathrm{C}_{2} \mathrm{H}_{6}$ & 5 & 115.6 & acetone \\
$3,6-\mathrm{B}_{5} \mathrm{C}_{2} \mathrm{H}_{7}$ & 5 & 112.8 & neat liquid \\
$2,3-\mathrm{B}_{9} \mathrm{C}_{2} \mathrm{H}_{11}$ & 5 & 106.3 & toluene \\
$1,5-\mathrm{B}_{3} \mathrm{C}_{2} \mathrm{H}_{5}$ & 4 & 90.4 & CS \\
\hline$+\delta \mathrm{CS}_{2}=0 \mathrm{ppm}$ & & &
\end{tabular}




\section{J. TODD}

the c.m.r. chemical shift of these two carbon nuclei. The range of c.m.r. chemical shifts for each coordination number is approximately $20 \mathrm{ppm}$ and there is some overlap.

Caution should be exercised in assigning coordination numbers to carbon atoms whose chemical shift values lie on the borderline of the c.m.r. chemical shift range.

\section{ACKNOWLEDGEMENTS}

Research results of my capable co-workers Don C. Beer, George M. Bodner, Aaron R. Burke, Steve B. Kahl, Allen R. Siedle, Howard T. Silverstein, Ray L. Sneath, Bruce N. Storhoff and Gerry S. Wikholm are discussed in this article. This research was carried out with the generous support of the Office of Naval Research and the National Science Foundation.

\section{REFERENCES}

1 J. L. Little, J. T. Moran and L. J. Todd, J. Am. Chem. Soc. 89, 5495 (1967).

2 L. J. Todd, J. L. Little and H. T. Silverstein, Inorg. Chem. 8, 1698 (1969).

3 L. I. Zakharkin and V. I. Kyskin, Zh. Obshch. Khim. 40, 2241 (1970).

${ }^{4}$ L. J. Todd, I. C. Paul, J. L. Little, P. S. Welcker and C. R. Peterson, J. Am. Chem. Soc. 90, 4489 (1968).

${ }^{5}$ H. T. Silverstein, D. C. Beer and L. J. Todd, J. Organomet. Chem. 21, 139 (1970).

6 J. L. Little, P. S. Welcker, N. J. Loy and L. J. Todd, Inorg. Chem. 9, 63 (1970).

D. C. Young, D. V. Howe and M. F. Hawthorne, J. Am. Chem. Soc. 91, 859 (1969).

8 W. A. G. Graham, Inorg. Chem. 7, 315 (1968).

${ }^{9}$ M. Y. Darensbourgh and D. J. Darensbourgh, Inorg. Chem. 9, 32 (1970).

10 L. J. Todd, A. R. Burke, H. T. Silverstein, J. L. Little and G. S. Wikholm. J. Am. Chem. Soc. 91, 3376 (1969).

11 J. C. Smart, P. M. Garrett and M. F. Hawthorne, J. Am. Chem. Soc. 91.1031 (1969).

12 A. R. Pitochelli and M. F. Hawthorne, J. Am. Chem. Soc. 84, 3218 (1962).

13 P. G. Simpson and W. N. Lipscomb, Proc. Nat. Acad. Sci. US, 48. 1490 (1962).

14 P. G. Simpson, K. Folting and W. N. Lipscomb, J. Am. Chem. Soc. 85, 1879 (1963).

15 R. L. Sneath, J. L. Little, A. R. Burke and L. J. Todd, Chem. Commun. 693 (1970).

16 F. Klanberg, P. A. Wegner, G. W. Parshall and E. L. Muetterties, Inorg. Chem. 7. 2072 (1968).

17 D. E. Hyatt, D. A. Owen and L. J. Todd, Chem. Commun. 503 (1965).

${ }_{18}$ M. M. Fein, J. Bobinski, N. Mayes, N. Schwartz and M. S. Cohen, Inorg, Chem. 2, 1111 (1963).

${ }^{19}$ L. I. Zakharkin, V. N. Kalinin and L. S. Podvisotskaya, Izvest. Akad. Nauk SSSR, Ser. Khim. $1495(1966)$.

${ }^{20}$ G. B. Dunks, M. M. McKown and M. F. Hawthorne, J. Am. Chem. Soc. 93. 2541 (1971).

21 D. E. Hyatt, F. R. Scholer and L. J. Todd, Inorg. Chem. 6, 630 (1967).

22 G. M. Bodner, F. R. Scholer, L. J. Todd, L. E. Senor and J. C. Carter, Inorg. Chem. 10, 942 (1971).

23 A. R. Siedle, G. M. Bodner and L. J. Todd, to be published.

24 A. R. Siedle, G. M. Bodner and L. J. Todd, J. Organomet. Chem. 33, 137 (1971).

${ }^{25}$ F. P. Boer, R. A. Hegstrom, M. D. Newton, J. A. Potenza and W. N. Lipscomb. J. Am. Chem. Soc. 88,5340 (1966).

${ }^{26}$ R. E. Williams, Progress in Boron Chemistry 2, 103 (1970).

27 B. F. Spielvogel and J. M. Purser, J. Am. Chem. Soc. 89, 5294 (1967). 